\title{
Effect of Calving Interval on Milk Yield in Italian Buffalo Population
}

\author{
E. Parlato ${ }^{1, *}$ and L. Zicarelli ${ }^{2}$ \\ ${ }^{1}$ M'ama Buffalo Welfare Science and Technology, via G. Alviani, 31 Capua, ITA, Italy \\ ${ }^{2}$ Animal Production Department, Faculty of Veterinary, University of Naples Federico II, ITA, Italy
}

\begin{abstract}
The objective of this study was to investigate the effect of the previous calving intervals $(\mathrm{Cl})$ on milk yield (MY) in the current lactation for the Italian buffalo breed population.

Data for 86,585 lactation records from the Italian Buffalo Breeders Association database, were analyzed. MY BLUPestimates were obtained by including in the Animal Model the fixed effects of age-parity, previous $\mathrm{Cl}$, and herdcontemporary-group. The MY solutions for the months of $\mathrm{Cl}$ were analyzed with the linear regression model where $\mathrm{Cl}$ in months was the explanatory variable. 59.66\% of the lactation records had Cl between 11 and 14 months. $37.91 \%$ of the lactation records were distributed between 15 and 24 months. The smaller percentage of records showed $\mathrm{Cl}$ greater than 24 months. This $\mathrm{Cl}$ distribution may be, in part, the result of herd management strategies. Dairy producers try to shorten the $\mathrm{Cl}$ of their herd in order to get the most profit from early conceptions of the buffalo. The regression model and its parameters were statistically significant. The coefficient of determination was equal to 0.58 . The intercept was equal to $72.42 \mathrm{~kg}$; and the linear coefficient (b) was equal to -3.43 . The negative value of $b$ denotes a negative effect of $\mathrm{Cl}$ on MY. This result indicates that there is a negative linear relationship between previous $\mathrm{Cl}$ and $\mathrm{MY}$ in the current lactation. Therefore, shorten the $\mathrm{Cl}$ may increase the profits of the farm through higher $\mathrm{MY}$, because it has less of a negative effect on MY than longer $\mathrm{Cl}$.
\end{abstract}

Keywords: Italian Mediterranean Buffalo, milk yield, calving interval.

\section{INTRODUCTION}

Calving interval is the fertility index widely used at the small farm level for Italian buffalo. Under herd conditions, a buffalo usually produces two calves in three years. But in well- managed herds of dairy buffalo, calving intervals of 11-12 months have been achieved. In dairy cows, calving interval is highly dependent on year and season of breeding $[1,2]$ and on farm management and herd size [3]. Increases in the interval from the first to the sixth lactation was observed in the US dairy population [4]. Although, Syed M. et al. [5] showed higher calving intervals in primiparous then in pluriparous buffalo. Other factors that may affect the length of calving intervals in buffalo, are conception rate [6], buffalo age [6,7], and service sire [8]. In dairy cows, high milk production lead to longer calving intervals $[9,10,11]$.

Prolonged calving interval in buffalo is primarily related to delayed breeding. Breeding may be delayed by prevalence of silent estrus, summer infertility, low progesterone levels [12], lower LH levels [13] and suckling [14]. Seasonality of breeding and nutritional status are additional contributing factors [15, 16]. Month of calving had significant effects on calving interval in the Italian buffalo population [17]. Females that calved between April and September had shorter

*Address correspondence to this author at the M'ama Buffalo Welfare Science and Technology, via G. Alviani, 31 Capua, ITA, Italy; Tel: 00393898853266; E-mail: manup9@gmail.com intervals than those calving between October and December [17]. Because buffalo are less sensitive to high temperatures than bovine, they tend to reproduce more efficiently during the warmest months of the year [17].

The general practice in both buffalo and bovine dairy herds with intensive milk production, is to breed cows with the aim of establishing a calving interval of 12 months. This traditional breeding system is based on the idea that the production economy benefits from an early conception $[18,19,20]$. In order to shorten the calving interval, the female should be bred as soon as possible after calving. However, the relationship between time intervals from calving to eventual conception and various physiological, environmental, and management features make it difficult to determine how to manage for optimum length of calving interval. High milk yields and 12 month calving intervals cause general concerns about metabolic diseases. It has been shown that increasing milk yield leads to an increase in the frequencies of metabolic diseases, such as ketosis and milk fever [21]. Cows with short calving intervals tend to be discarded after just one or two lactations. The most common reason for culling is fertility problems, which account for as much as $25 \%$ of the culled cows [22]. Even though several studies suggest an optimal calving interval of near 12 months, there are studies that have shown an advantage for a longer period of days open and, consequently, an extended calving interval [23]. Gaines W. L. and Palfrey G.R [24] found a negative correlation between 
calving interval and milk yield. Increases in calving intervals over time have been reported in dairy cow populations in many countries, including Spain [25], and the United Kingdom [26]. Although the economic importance of Italian buffalo has always been known, very little work has been done to evaluate the effect of the previous calving interval on milk yield on the current lactation in the buffalo species.

The objective of this study was to evaluate the effect of the previous calving interval on milk yield in the current lactation for the Italian buffalo breed population.

\section{MATERIALS AND METHODS}

\section{Data}

Data for 86,585 lactation records from the Italian Buffalo Breeders Association (ANASB) database, were used to determine the effect of previous calving intervals $(\mathrm{Cl})$ on milk yield (MY) for the Mediterranean Italian buffalo breed. Only records from buffalo with a calving date after December 31, 1980, were included in the analyses. All records were extended to 270 days for lactations less than 270 days. Editing consisted of accepting only lactation records of buffalo having more than 150 or less than 570 days of lactation and having, in the current lactation, calving to conception intervals (days open) between 20 and 730 days. Parities were grouped into three different classes: parities 1, 2 and $\geq$ 3. Days open (DO) in the current lactation was approximated by taking the difference between two consecutive calving intervals and subtracting the length of the average buffalo gestation period (310 days). For first lactations an average DO of 170 days was assigned. Lactation records were grouped into seven DO classes: DO were rounded to the nearest month to form classes corresponding to months 1 to 6 . Months $\geq$ 7 constituted the last class. Contemporary groups were formed by grouping records of buffalo calving in the same herd in the same year and season of calving within the year. Three seasons of calving were defined: January to April; May to August; and September to December. This dataset was reduced by removing records in contemporary groups in herds with number of observations less than five for the variance components estimation and less than two for the genetic evaluation. $\mathrm{Cl}$ were calculated as the number of months between two calving dates. Records for a cow were excluded if the calving interval was less than 11 months or greater than 30 months. Each month of $\mathrm{Cl}$ (from 11 to 30 months) represented a single class.
After preliminary analyses, parities were grouped into three different classes: parities 1,2 and equal to or greater than 3. Ninety-three age classes were formed. Twenty-one classes were assigned to parity 1, twentynine classes were assigned to parity 2, and forty-three classes were assigned to parities equal to or greater than 3. All age classes contained a single age in months, with the exception that the last class in parities equal to or greater than 3 included all ages greater than 90 months. This data set was reduced by removing contemporary groups with a number of observations less than five.

\section{Statistical Models}

Two statistical analyses were used sequentially in evaluating the effect of the previous $\mathrm{Cl}$ on $\mathrm{MY}$ in the current lactation. Estimates of MY (expressed as deviations from the mean) from the first analysis were used in the second analysis. The first analysis included the fixed effects of age-parity, previous calving interval, and herd contemporary group. The MTDFREML programs [27] were used for this analysis.

The second analysis fit the solutions of MY for the effect of months of $\mathrm{Cl}$ from the first analysis using linear regression, where $\mathrm{Cl}$ class in months from 11 to 30 was the explanatory variable. PROC REG, the linear regression procedure of SAS [28] was used for this analysis.

\section{RESULTS AND DISCUSSION}

Summaries of number and frequencies of records, and unadjusted means for MY by class of $\mathrm{Cl}$ are shown in Table 1. Most of the records are distributed between $\mathrm{Cl}$ of 11 and 14 months (59.66\%). This distribution of $\mathrm{Cl}$ may be, in part, the result of herd management strategies. Dairy producers try to shorten the $\mathrm{Cl}$ of their herd in order to get the most profit from early conceptions of the cows [18, 19, 20]. Average MY slightly varied among $\mathrm{Cl}$ classes. In general, lactation records with longer $\mathrm{Cl}$ showed greater $\mathrm{MY}$ than lactation records whose previous $\mathrm{Cl}$ were shorter. These results agree with previous experimental studies $[9,10,11]$ that found longer $\mathrm{Cl}$ in high milk production cows.

The regression model was statistically significant (Table 2). The coefficient of determination $\left(R^{2}\right)$ was equal to 0.58 . The intercept (a) was equal to $72.42 \mathrm{~kg}$; and the linear coefficient (b) was equal to -3.43 . Both coefficients estimated were also statistically significant. 
Table 1: Number of Records (N), Frequencies of Records (\%) with Average Means for Milk Yield (kg) by Classes of Cl in Months

\begin{tabular}{|c|c|c|c|}
\hline $\mathrm{Cl}$ & $\mathbf{N}$ & Frequency & Average milk yield \\
\hline 11 & 12,096 & 13.74 & 2,356 \\
\hline 12 & 18,724 & 21.26 & 2,361 \\
\hline 13 & 12,910 & 14.66 & 2,374 \\
\hline 14 & 8,806 & 10.00 & 2,372 \\
\hline 15 & 6,800 & 7.72 & 2,394 \\
\hline 16 & 5,707 & 6.48 & 2,386 \\
\hline 17 & 5,388 & 6.12 & 2,406 \\
\hline 18 & 4,421 & 5.02 & 2,402 \\
\hline 19 & 3,323 & 3.77 & 2,411 \\
\hline 20 & 2,369 & 2.69 & 2,428 \\
\hline 21 & 1,688 & 1.92 & 2,411 \\
\hline 22 & 1.446 & 1.64 & 2,441 \\
\hline 23 & 1,259 & 1.43 & 2,427 \\
\hline 24 & 984 & 1.12 & 2,422 \\
\hline 25 & 673 & 0.76 & 2,437 \\
\hline 26 & 434 & 0.49 & 2,362 \\
\hline 27 & 340 & 0.39 & 2,404 \\
\hline 28 & 280 & 0.32 & 2,369 \\
\hline 29 & 211 & 0.24 & 2,254 \\
\hline 30 & 195 & 0.22 & 2,348 \\
\hline
\end{tabular}

Table 2: Parameters of the Equation ${ }^{1} \mathrm{y}_{\mathrm{ij}}=\mathrm{a}+\mathrm{bx}_{\mathrm{j}}$ to Predict Milk Yield $(\mathrm{kg})$ at Various Interval of $\mathrm{Cl}$ in Months

\begin{tabular}{|c|c|c|c|c|}
\hline Parameter & Estimate & Std. Error & t- value & Pr $>\mathbf{t}$ \\
\hline \hline $\mathrm{a}$ & 72.42 & 14.45 & 5.01 & $<0.0001$ \\
\hline $\mathrm{b}$ & -3.43 & 0.68 & -5.06 & $<0.0001$ \\
\hline
\end{tabular}

${ }^{1} \mathrm{y}=$ milk yield at various interval from parturition; $\mathrm{x}=\mathrm{Cl}$.

The negative value of $b$ denotes a negative effect of months of $\mathrm{Cl}$ on MY.

Solutions by month of $\mathrm{Cl}$ on $\mathrm{MY}$ from the management adjusted model and the predictions from the linear model expressed as deviation from the mean of $M Y(2,356 \mathrm{~kg})$ are shown in Table 3 . Solutions ranged between $-80.60 \mathrm{~kg}$ and $32.69 \mathrm{~kg}$, respectively for 29 and 15 months of $\mathrm{Cl}$. Whereas, the liner predictions ranged between $-29.58 \mathrm{~kg}$ and $35.02 \mathrm{~kg}$, respectively for 30 and 11 months of $\mathrm{Cl}$.

The solutions and the predictions by $\mathrm{Cl}$ on $\mathrm{MY}$ are presented in Figure 1. The linear model was a good fit of the management adjusted MY solutions for $\mathrm{Cl}$ between 11 and 24 months. Whereas, the solutions for the other $\mathrm{Cl}$ classes exhibited greater deviations from their linear prediction. The small number of records in those classes, or some kind of error in reporting calving dates, could be an explanation of those outliers. As shown from the graph, there was a negative relationship between $\mathrm{MY}$ and $\mathrm{Cl}$ length. For each month increase in $\mathrm{Cl}$, there was an approximate drop of $3.5 \mathrm{~kg}$ in MY, which leads to a decrease of close to $60 \mathrm{~kg}$ from 11 to 24 month $\mathrm{Cl}$. This result agrees with the finding of Gaines W. L. and Palfrey G.R [24] that demonstrated a negative correlation between $\mathrm{Cl}$ and MY. There may be a physiological reason for the negative correlation between $\mathrm{Cl}$ length and milk production. In fact, for longer $\mathrm{Cl}$, the mammary gland may become quiescent. And, it may regress to a 
Table 3: Management Adjusted Solutions $\mathrm{s}^{\mathrm{a}}$ and Linear Predictions ${ }^{\mathrm{b}}$ of Milk Yield by $\mathrm{Cl}$ (Months) Expressed as Deviation from the Mean Milk Yield $(2,356 \mathrm{~kg})$

\begin{tabular}{|c|c|c|}
\hline \multirow{2}{*}{ Cl } & \multicolumn{2}{|c|}{ Milk yield solutions } \\
\hline & Management adjusted & Linear prediction \\
\hline 11 & 27.11 & 35.02 \\
\hline 13 & 20.49 & 28.22 \\
\hline 14 & 19.36 & 24.82 \\
\hline 16 & 22.30 & 18.02 \\
\hline 17 & 20.07 & 14.62 \\
\hline 18 & 1.49 & 11.22 \\
\hline 19 & 9.96 & 7.82 \\
\hline 20 & 9.63 & 4.42 \\
\hline 24 & 0.00 & -9.18 \\
\hline 25 & 11.42 & -12.58 \\
\hline 26 & -30.90 & -15.98 \\
\hline 27 & 5.19 & -19.38 \\
\hline 28 & -31.58 & -22.78 \\
\hline 29 & -80.60 & -26.18 \\
\hline 30 & -20.73 & -29.58 \\
\hline
\end{tabular}

${ }^{a}$ Effects included in management adjusted model were: age-parity class, Cl class, and contemporary group in herd as fixed effects; and residual error as random effect.

${ }^{b}$ Effects included in the linear prediction model were: intercept and linear coefficient of regression of $\mathrm{Cl}$ on milk yield solutions from the management adjusted model.

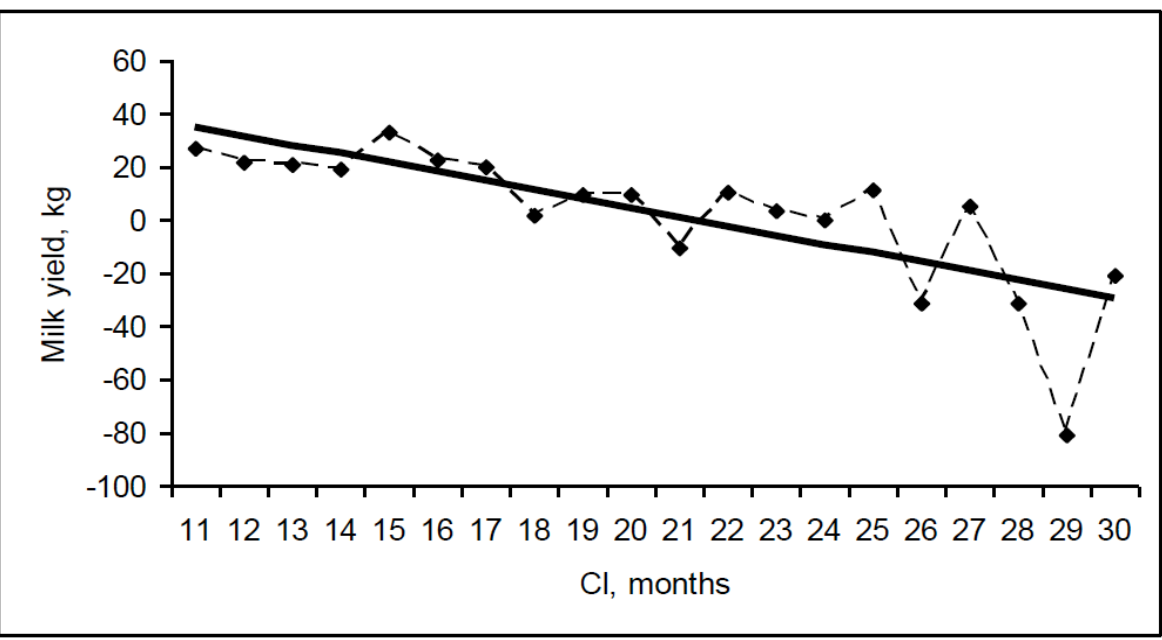

Figure 1: Plots of average solutions for $\mathrm{Cl}$ classes from management adjusted model (- -) and predictions from linear prediction model (-) for milk yield expressed as deviation from the mean milk yield $(2,356 \mathrm{~kg})$.

primitive status, similar to that of a primiparous. Thus, longer $\mathrm{Cl}$ will lead to lower milk production.

\section{CONCLUSION}

The present study indicates that there is a negative linear relationship between previous $\mathrm{Cl}$ length and $\mathrm{MY}$ in the current lactation in the Italian buffalo population. This means that shorter previous $\mathrm{Cl}$ have less of a negative effect on milk production of Italian Mediterranean buffalo than longer previous $\mathrm{Cl}$. Therefore, a short $\mathrm{Cl}$ may increase the profits of the farm through higher milk production. 


\section{REFERENCES}

[1] Gwazdauskas FC, Wilcox CJ, Thatcher WW. Environmental and managemental factors affecting conception rate in a subtropical climate. J Dairy Sci 1975; 58: 88-92.

http://dx.doi.org/10.3168/jds.S0022-0302(75)84523-1

[2] Marques JR, Ramos AA, Silva MET, Costa NL. Syed, M.; Zafarullah, Khan; shah, M. A. P. 1996; 4131.

[3] Shrivastava AK, Singh CSP, Verma SK, Dutta OP. Dry period and calving interval in buffaloes maintained under farmers' management conditions. Journal of Research, Birsa Agricultural University 1996; 8: 193-195.

[4] Nieuwhof GJ, Powell RL, Norman HD. Ages at calving and calving interval for dairy cattle in the United States. J Dairy Sci 1989; 72: 685-692.

http://dx.doi.org/10.3168/jds.S0022-0302(89)79160-8

[5] Syed M, Zafarullah, Khan, Shah, MAP. Production performance, persistency of lactation and repeatability of some quantitative traits in Nili- Ravi buffaloes. Sarhad Journal of Agriculture 1996; 12: 1-9.

[6] Marion GB, Gier HT. Factors affecting bovine ovarian activity after parturition. J Anim Sci 1968; 27: 1621-1626.

[7] Morrow DA. Postpartum ovarian activity and involution of the uterus and cervix in dairy cattle. Vet Scope 1969; 14: 2.

[8] Gwazdauskas FC, Thatcher WW, Wilcox CJ. Physiological, environmental, and hormonal factors at insemination which may affect conception. J Dairy Sci 1973; 56: 873-877. http://dx.doi.org/10.3168/ids.S0022-0302(73)85270-1

[9] Everett RW, Armstrong DV, Boyd LJ. Genetic relationship between production and breeding efficiency. J Dairy Sci 1966; 49: 879-886.

http://dx.doi.org/10.3168/jds.S0022-0302(66)87963-8

[10] Smith JW, Legates JE. Relation of days open and days dry to lactation milk and fat yields. J Dairy Sci 1962; 45: 11921198. http://dx.doi.org/10.3168/jds.S0022-0302(62)89595-2

[11] Touchberry RW, Rottensten K, Andersen H. Associations between service interval, interval from first service to conception, number of services per conception, and level of butterfat production. J Dairy Sci 1959; 42: 1157-1170. http://dx.doi.org/10.3168/ids.S0022-0302(59)90708-8

[12] Qureshi MS, Ahmad N. Interaction among calf suckling, use of oxytocin, milk production and reproduction in dairy buffaloes. Anim Reprod Sci 2007; 106: 380-392. http://dx.doi.org/10.1016/j.anireprosci.2007.05.019

[13] Batra SK, Pandey RS. Relative concentration of 13-14dihydro-15 keto prostaglandin $\mathrm{F} 2 \mathrm{a}$ in blood and milk of buffaloes during the estrus cycle and early pregnancy. $J$ Reprod Fertil 1983; 67: 191-196. http://dx.doi.org/10.1530/jrf.0.0670191

[14] Perera BM, A. O., Mohan V, Kurovita VY, Abeygunawardena $\mathrm{H}$. Effect of suckling and nutritional supplementation on postpartum ovarian activity and $\mathrm{LH}$ profiles in indigenous buffaloes of Sri Lanka. In: Proc. 12th Int. Cong. Animal
Reprod. Artif. Insem, The Hague, The Netherlands, 1992; pp. 2081-2083.

[15] Qureshi MS, Samad HA, Habib G, Usmani RH, Siddiqui MM. Study on factors leading to seasonality of reproduction in dairy buffaloes. I. Nutritional factors. Asian-Aust J Anim Sci 1999a; 12(7): 1019-1024.

[16] Qureshi MS, Habib G, Samad HA, Lodhi LA, Usmani RH. Study on factors leading to seasonality of reproduction in dairy buffaloes. II. Non-nutritional factors. Asian-Aust. J Anim Sci 1999b; 12(7): 1025-1030.

[17] Zicarelli L, Di Palo R, Neglia G, Ariota B, Varricchio E, Campanile G. Estimation of the intercalving period in Italian Mediterranean buffalo. Proceedings VIII World Buffalo Congress, Caserta, Italy, October 19-22,2007. In: Italian Journal of Animal Science 2007; 6(Suppl. 2 - Part 1): 709712.

[18] Holmann FJ, Shumway CR, Blake RW, Schwart RB, Sudweeks EM. Economic value of days open for Holstein cows of alternative milk yields with varying calving intervals. $J$ Dairy Sci 1984; 67: 36-643.

http://dx.doi.org/10.3168/jds.S0022-0302(84)81349-1

[19] Maijala K. Fertility as a breeding problem in artificially bred populations of dairy cattle. I. Registration and heritability of female sterility. Ann Agr Fenn Suppl 1964; 1-3: 1-94.

[20] Pelissier CL. Herd breeding problems and their consequences. J Dairy Sci 1972; 55: 385-391. http://dx.doi.org/10.3168/jds.S0022-0302(72)85502-4

[21] Distl O, Wurm A, Glibotic A, Brem G, Krausslich H. Analysis of relationships between veterinary recorded production diseases and milk production in dairy cows. Livestock Production Science 1989; 23: 67-78. http://dx.doi.org/10.1016/0301-6226(89)90006-7

[22] Swedish Dairy Association. Cattle statistics. Svensk Mjölk, 63184 Eskilstuna, Sweden 2002.

[23] Bar-Anan R, Soller M. The effects of days-open on milk yield and on breeding policy post partum. Animal Production 1979; 29: $109-119$.

http://dx.doi.org/10.1017/S0003356100012204

[24] Gaines WL, Palfrey JR. Length of calving interval and average milk yield. J Dairy Sci 1931; 14: 294-306. http://dx.doi.org/10.3168/jds.S0022-0302(31)93474-7

[25] González-Recio O, Pérez-Cabal MA, Alenda R. Economic value of female fertility and its relationship with profit in Spanish dairy cattle. J Dairy Sci 2004; 87: 3053-3061.

[26] Wall E, Brotherstone S, Woolliams JA, Banos G, Coffey MP. Genetic evaluation of fertility using direct and correlated traits. J Dairy Sci 2003; 86: 4093-4102. http://dx.doi.org/10.3168/jds.S0022-0302(03)74023-5

[27] Boldman KG, Kriese LA, Van Vleck LD, Van Tassell CP, Kachman SD. A manual for use of MTDFREML. A set of programs to obtain estimates of variances and covariances. Agric. Res. Serv., USDA, Washington, DC 1995.

[28] SAS/STAT User's Guide, Version 9.1. 2005. Cary, NC: SAS Institute. 